12. Pro stymulyuvannya rynku kryptovalyut ta yikh pokhidnykh v Ukrayini : Proekt Zakonu Ukrayiny vid 10.10.2017 №7183-1 [On the Encouragement of the Cryptocurrency Markets and Their Derivatives in Ukraine: Draft Law of Ukraine] URL http://w1.c1.rada.gov.ua/pls/zweb2/webproc4_1?pf3511=62710 [in Ukr.]

13. Pro obih kryptovalyuty v Ukrayini : Proekt Zakonu Ukrayiny vid 06.10.2017 № 7183 [On the Circulation of Cryptocurrency in Ukraine: Draft Law of Ukraine] URL : http://w1.c1.rada.gov.ua/pls/zweb2/webproc4_1?pf3511=62684 [in Ukr.]

14. Marks, K. (1967) Kapital [Capital.] M.: Izd-vo polit. lit., 907 s. [in Ukr.]

15. Chaplian, S.Ye. (2018) Pravovyi status kryptovaliut / Zovnishnia torhivlia: ekonomika, finansy, pravo [Legal status of cryptocurrencies / Foreign trade: economy, finance, law.] №2. St. 145168. URL : https://jusguard.com.ua/uk/publications/legal-status-of-cryptocurrency [in Ukr.]

\title{
Summary
}

The aspects of financial and economic security are considered and the analysis of currently known cryptocurrencies and a wide range of interpretations of the concept of "cryptocurrency" by official bodies of different countries are carried out; forecasting the development of cryptocurrencies for accounting for formalizing factors that affect the value of cryptocurrencies. The evolution of cryptocurrency has been analyzed and its further development projected as a powerful financial instrument in the world market. The purpose of the article is to analyze the aspects of financial and economic security by predicting the development of cryptocurrencies by formalizing the factors that affect the value of cryptocurrencies. The emergence of cryptocurrency was made possible by cryptographÿ and the principle of cryptocurrency turnover based on blockchain technology.

Keywords: cryptocurrency, bitcoin, ethereum, lightcoin, nemkoin, mining, money, blockchain .

UDC 338.1

DOI: $10.31733 / 2078-3566-2019-5-249-259$

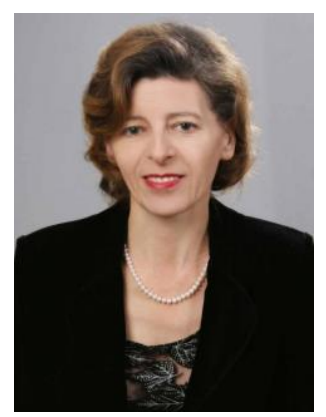

Zoya KALINICHENKO ${ }^{\odot}$

Ph.D

(Dnipropetrovsk State University of Internal Affairs)

\section{PROBLEMS OF INSTITUTIONAL AND LEGAL SUPPORT FOR OVERCOMING STRUCTURAL IMBALANCES IN UKRAINE'S DEVELOPMENT}

ЗоЯ КалінічеНКо. ПРОБЛЕМИ ІНСТИТУЦЙНО-ПРАВОВОВОГО ЗАБЕЗПЕЧЕННЯ ПОДОЛАННЯ СТРУКТУРНИХ ДИСБАЛАНСІВ РОЗВИТКУ УКРАЇНИ. РозгЛЯдаються проблемні питання забезпечення економічного зростання в країнах 3 ринковою системою, що розвивається: структурна незбалансованість; керована, неринкова фінансово-монетарна політика; втрачання можливостей розвитку реального сектора економіки; управлінська неспроможність державно-владних інституцій.

На високий рівень теоретичного узагальнення проблем в наукових публікація вказують фахівці, як на досягнення. Але дослідження різних аспектів структурної незбалансованості, взаємозв'язків між діями державно-владних інституцій 3 метою зменшити та вирівняти їх негативний прояв, залишаються актуальними та потребують додаткових наукових розробок.

Автор розглядає перешкоди на шляху економічного зростання країн та пропонують їх класифікацію залежно від їх впливу, походження та функціонального змісту. Серед ризиків, що перешкоджають та створюють небезпеку, наводять саме такі, як слабкість державних інституцій, історично сформовану слабку соціальну структуру. Досліджується в працях учених діаметральна протилежність інтересів впливових соціальних груп, безвідповідальність, що пов'язана зі станом правової культури в суспільстві, нефаховість та прорахунки інститутів, що утримуються на державні кошти та повинні забезпечувати впровадження ринкових змін.

Дослідження присвячене розробці концептуальних засад, принципів та підходів до моделювання систем економічного зростання в країнах 3 ринковою трансформацією. На базі проведеного аналізу репрезентативного масиву інформації розкривається взаємозв'язок між складовими, що створюють небезпеку економічному зростанню, сталому розвитку країн;

\footnotetext{
(C) Kalinichenko Z., 2019

ORCID iD https://orcid.org/0000-0002-6045-1511

k_eam@dduvs.in.ua
} 
доводиться їх повторюваність або типовість, що створює особливі умови для розробки механізмів запобігання перешкодам, загрозам, ризикам та методів управління ними.

Автор, використовуючи методи діалектики, наукової абстракції та системного підходу, 3'ясовують зв'язки та ланцюги зв'язків, що характеризують галузеву незбалансованість та макроекономічні диспропорції та ведуть до них. Підкреслюється, що відкритість економіки сприяє підвищенню іiї ефективності, мобільності та конкурентоспроможності. Однак, враховуючи незрілість ринкових відносин та кризовий стан економіки, входження країни в міжнародний ринок потребує особливої уваги. Відкриваючи економіку, потрібно підвищувати рівень захисту та вимагати ефективності від вітчизняного виробника, фінансів, банківської системи, стратегічних галузей та підприємств.

Результати дослідження дозволили автору стверджувати, що наростаюча системна криза в соціально-політичній сфері держави мультиплікативно поширюється на систему забезпечення економічного зростання, яка втрачає свої функціональні можливості та потребує нових узгоджених та досконалих стратегічних пріоритетів розвитку та його інституційно-правового забезпечення, а також механізмів, інструментів та засобів трансформації ринкової системи.

Ключові слова: економічне зростання, дисбаланси, розвиток реального сектору, інструменти фінансово-монетарної політики, узгоджені пріоритети розвитку.

Problem statement. For the sustainable development of countries with a developing market system, significant structural impediments are structural imbalances of the economy, troubled government, non-market financial and monetary policies, and the absence of real sector growth policies. These obstacles become especially evident with the transition of countries to a competitive stage of the market economy, with the implementation of European integration and international cooperation programs.

It is the imbalances in the reform of the sectors, the structural imbalances, the poor public administration that are pushing the country back to decline and impoverishment, turning it into a "banana republic", into a raw material appendage.

The imbalance has a negative impact on economic processes, leading to large-scale use of corruption schemes and oligarchic lobbying in public authorities. Disproportions are a significant threat to economic growth and the national security of countries embarking on market reforms. The countries are weak because they have not overcome the contradictions of their historical past.

Analysis of publications that started solving this problem. The problems of largescale market reforming of the economy of Ukraine and countries with a developing market system have been investigated by various scientific schools, domestic and foreign scientists. The theoretical and methodological foundations of structural and sectoral imbalances, public administration and sustainable economic development were explored in their writings by Joseph Stiglitz [6, 10], Henry Farrell [7], Karl Polanyi [8], P Harrod [17], Sergei Guriev [27, 28] and other scholars. Among domestic economists, scientific studies of these problems have been conducted by Bogdan Danylyshyn [5], Zinoviy Varnaliy [12], Victor Kozyuk [29], Viktor Prisnyakov [31], Ruslan Leshchenko [30], Yuri Saveliev [2], Olga Solovyova [32 ], Andriy Novak [25] and others. They belong to the development of important aspects of macroeconomic problems related to the imbalances in the development of the market economy of countries, political populism and corruption, the quality of public administration.

Despite the considerable and high level of publications on sustainable development issues in transition economies, the issues of imbalance, managed monetary and real sector development remain relevant and require further research for Ukraine and other transition economies. The problem of overcoming the non-market "manual" management of macroeconomic indicators and financial and monetary policy instruments is urgent. This is the problem of the "patching of holes" policy in the country's budget, the problem of solving crises, not their prevention.

Most often, researchers at the global level of development of countries highlight socioeconomic imbalances in the following areas:

- GDP size and non-uniformity of this indicator for different countries of the world;

- the difference in the level of income of the population;

- the difference in the standard of living of the population - the income of the population, the availability of education and medical care, the levels of political and economic freedoms, life expectancy, etc .;

- external debt and its wide spread across countries;

- exports / imports and the fact that some countries have had a positive foreign trade balance for many years, while others have a negative balance;

Other imbalances include exchange rate imbalances, migration flows, tax rates, economic freedoms and others.

The article's objective is to find out the reasons for the imbalance in monetary and real 
sector growth policies in emerging market economies; in developing directions for improving the quality of public administration in such countries in order to ensure their economic growth.

Among the objectives of the study, the following should be mentioned:

- substantiation of the necessity to adjust the monetary and monetary policy of the real sector of the country;

- identification of links and linkages characterizing sectoral imbalances and macroeconomic imbalances;

- estimation of the depth of existing contradictions in the countries by different methods;

- development of measures to improve the quality of public administration, based on an assessment of the depth of disparities and contradictions in countries with a developing market system;

- development of ways to achieve macroeconomic equilibrium in conditions of economic instability in the country.

Basic content. The Ukrainian economy has such a peculiarity as a tendency to be exposed to external crises and economic conditions, which is caused by its low competitiveness. Among the reasons for this situation are technical backwardness, inefficiency of government, fiscal policy pressure, structural imbalance of development.

S.M. Mochernyi, Y.S. Larina, OA Ustenko and S.I. Yuri points out that the practice is typical when the state itself, through its unprofessional decisions, promotes corruption, shadowing the economy, offshore and capital outflows and resources. They define the shadow economy as a type of economic activity aimed at obtaining illicit income, evading state and public control and paying taxes on exports and imports [1, p. 447].

The factors of imbalance disorganize, lead to lagging countries with a transitional market economy, to the formation of a backward social structure of society. The implications of this in the transition economy are well known. The domination of pseudo-public and pseudo-private corporations leads to disparities in the dynamics of prices, the finances of the country. As a result, the national economy becomes a field of non-economic rivalry between corporate and bureaucratic structures, into the sphere of collision of their power and regulatory influences.

In countries with transformational economies, imperfect market mechanisms are:

- manual control of macroeconomic indicators and financial regulators;

- unprofessionality and miscalculations;

- political and oligarchic lobbying;

- mismatch of interests between social groups and their lack of motivation;

- strategic irresponsibility, only an anti-crisis approach without taking into account future actions.

If we take Ukraine, with all the positive achievements, statistics show that the economy is still shaky (Table 1).

Thus, Y. Saveliev stresses that the growth of macroeconomic indicators in Ukraine is not enough to close the gap in living standards with Western Europe.

Table 1

Indicators of nominal gross domestic product, consumer expenditures, exports and imports of goods and services in Ukraine in 2005-2018

\begin{tabular}{|l|l|l|l|l|l|l|l|l|l|}
\hline Year & $\begin{array}{l}\text { Nominal } \\
\text { GDP for } \\
\text { the year }\end{array}$ & \multicolumn{3}{l}{ Consumer costs } & \multicolumn{2}{l}{$\begin{array}{l}\text { Gross Exchang- } \\
\text { ing }\end{array}$} \\
\cline { 2 - 11 } & $\begin{array}{l}\text { Exports } \\
\text { million } \\
\text { UAH }\end{array}$ & $\begin{array}{l}\text { million } \\
\text { UAH }\end{array}$ & $\%$ & $\begin{array}{l}\text { million } \\
\text { UAH }\end{array}$ & $\%$ & $\begin{array}{l}\text { million } \\
\text { UAH }\end{array}$ & \% & $\begin{array}{l}\text { Import } \\
\text { million } \\
\text { UAH }\end{array}$ & \%oods \\
\hline $\mathbf{2 0 0 5}$ & 441452 & 337879 & 76.5 & 99876 & 22.6 & 227252 & 51.5 & -223555 & -50.6 \\
\hline $\mathbf{2 0 0 6}$ & 544153 & 424060 & 77.9 & 134740 & 24.8 & 253707 & 46.6 & -269200 & -49.5 \\
\hline $\mathbf{2 0 0 7}$ & 720731 & 558581 & 77.5 & 203318 & 28.2 & 323205 & 44.8 & -364373 & -50.6 \\
\hline $\mathbf{2 0 0 8}$ & 948056 & 758902 & 80.0 & 264883 & 27.9 & 444859 & 46.9 & -520588 & -54.9 \\
\hline $\mathbf{2 0 0 9}$ & 913345 & 772826 & 84.6 & 155815 & 17.1 & 423564 & 46.4 & -438860 & -48.0 \\
\hline $\mathbf{2 0 1 0}$ & 1082569 & 914230 & 84.5 & 199918 & 18.5 & 549365 & 50.7 & -580944 & -53.7 \\
\hline $\mathbf{2 0 1 1}$ & 1316600 & 1105201 & 83.9 & 282474 & 21.5 & 707953 & 53.8 & -779028 & -59.2 \\
\hline $\mathbf{2 0 1 2}$ & 1408889 & 1269601 & 90.1 & 257335 & 18.3 & 717347 & 50.9 & -835394 & -59.3 \\
\hline $\mathbf{2 0 1 3}$ & 1454931 & 1350220 & 92.8 & 228474 & 15.7 & 681899 & 46.9 & -805662 & -55.4 \\
\hline $\mathbf{2 0 1 4}$ & 1566728 & 1409772 & 90.0 & 220968 & 14.1 & 770121 & 49.2 & -834133 & -53.2 \\
\hline $\mathbf{2 0 1 5}$ & 1979458 & 1715636 & 86.7 & 303297 & 15.3 & 1044541 & 52.8 & -1084016 & -54.8 \\
\hline $\mathbf{2 0 1 6}$ & 2383182 & 2018854 & 84.7 & 512830 & 21.5 & 1174625 & 49.3 & -1323127 & -55.5 \\
\hline $\mathbf{2 0 1 7}$ & 2982920 & 2552525 & 85.6 & 618914 & 20.7 & 1430230 & 47.9 & -1618749 & -54.3 \\
\hline $\mathbf{2 0 1 8}$ & 3558706 & 3196756 & 89.8 & 667953 & 18.8 & 1608890 & 45.2 & -1914893 & -53.8 \\
\hline
\end{tabular}


Ukraine has not lost its Soviet heritage in economics, politics, and society. Ukraine's socialist legacy is greater than in the Baltic States or Poland.

This should be taken into account when planning further development steps. Especially when it comes to restrictive factors and pressure on the state [2, p. 214]. Ukraine, which seeks to reach the level of EU countries, has a chance.

Researches by sociologists Ronald Inglehart and Christian Welzel (Ronald Inglehart, 2015) indicate their confidence in the modernization of Ukrainian society. They believe that the interventions of the national government, local authorities, international organizations, civil society will have a positive impact on modernization, governance, promotion and economic growth.

The successes of developing countries are an example of such interventions. But such interventions should not be limited to economic policy alone. The state is not the exclusive source of such interventions. Society plays an important role, the self-organization of capable, motivated and competent participants.

In 2018, Ukraine's economy has grown the most over the past seven years. In comparison with 2017, the real gross domestic product increased by $3.3 \%$ in comparison with 2017 (Fig. 1). The nominal GDP amounted to UAH 3558.7 billion, and the GDP per capita amounted to UAH 84190.

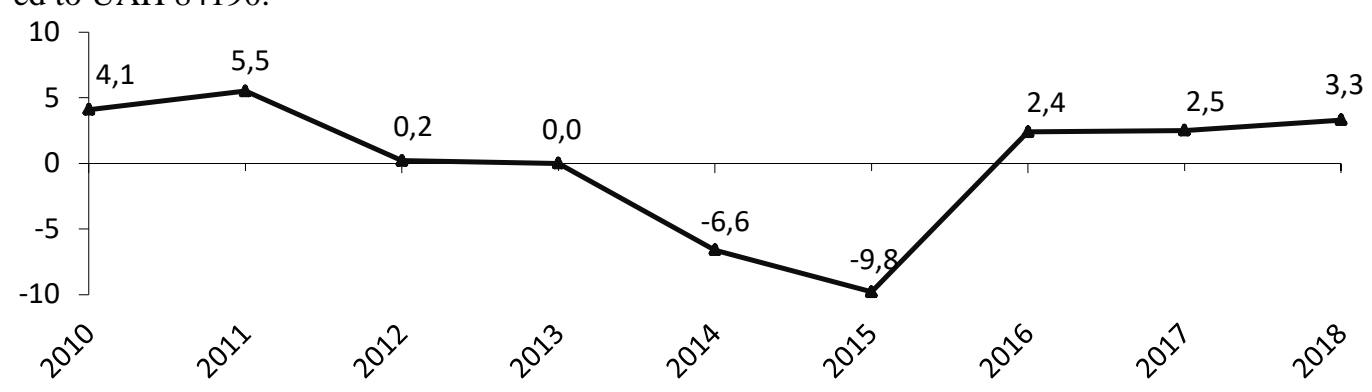

Fig 1. Real GDP change in Ukraine in $2010-2018$ (\% of previous year)

Source: According to the State Statistics Service of Ukraine [4]

According to B. Danylyshyn and NBU specialists, due to the tight monetary policy required to reduce inflation and the restrained fiscal policy caused by the repayment of large amounts of public debt, real GDP growth can slow down to $2.5 \%$ [5].

Nobel Laureate Joseph Stiglitz (Joseph Stiglitz, 2008) wrote: "Many former communist countries have turned to capitalism for the most part, but some have opted for a distorted market economy. They replaced their god Karl Marx with a new one - Milton Friedman. But the new religion does not serve them well " $[6$, p. 125]. The absence of that overwhelming force in the market is confirmed every time in practice.

Speaking about his book, The Power of Market Fundamentalism: A Critique of Karl Polanyi (Harvard, University Press, 2014), Henry Farrell argues that the ideas of Carl Polanyi, author of The Great Transformation, a classic of 20th-century political economy, are crucial if you want to understand the recession and its consequences [7]. Representatives of neoclassical economic theory believe that market principles are dominant not only in the economy, but in all other spheres of life. However, Polanyi (John, December 2010) convincingly argued that even in the system of economic life, market principles were almost never dominant ... Government activity is not an "interference" with the autonomous sphere of economic activity. There is simply no economy without government rules and institutions [8].

The state in Ukraine still plays a significant and special role. At the present stages of civil society, its individual elements play the role of anti-development institutions. They are turning into powerful public coalitions that deal with the allocation of significant state resources. They manage to influence state decisions at the expense of state sources and to exist at the junction of the state and civil society. Nobel laureate J. Buchanan (J. Buchanan, 1986) wrote that the existence of such antistructures has dramatic consequences. Distributive coalitions (oligarchic groups, predatory elites, state institutions) artificially inhibit development [9, p. 217]. In the world economy, imperfect market reforms and defenseless globalization have struck. No country, region, or bloc is unstable. It will not continue in the future, Stiglitz warns, unless the rules governing macroeconomics and globalization are rewritten [10, p. 268]. 
Table 2

Dynamics of GDP growth of countries at market prices and its forecast parameters for 2020-2021 (USD 2010 prices)

\begin{tabular}{|l|l|l|l|l|}
\hline Year & Ukraine & Poland & Turkey & EU \\
\hline 2016 & 2,4 & 3,1 & 3,2 & 1,9 \\
\hline 2017 & 2,5 & 4,8 & 7,4 & 2,4 \\
\hline 2018 & 3,3 & 5,1 & 2,6 & 1,9 \\
\hline 2019 (forecast) & 2,7 & 4,0 & 1,0 & 1,6 \\
\hline 2020 (forecast) & 3,4 & 3,6 & 3,0 & 1,5 \\
\hline 2021 (forecast) & 3,8 & 3,3 & 4,0 & 1,3 \\
\hline
\end{tabular}

Source: Compiled by Global Economics Prospects Report, Worldbank [11]

There are positive trends in Ukraine. However, real growth is not significant. The main reason for the slow growth is the lack of strategy.

The characteristics of the quality side of economic growth are complemented by a comparison of economic growth with population growth. For example, Ukraine has recently been characterized by slow economic growth and insufficient domestic production, and increased inflationary pressures. Accordingly, the increased interest rate, which reaches $15-17 \%$ per annum, which impedes economic development accordingly (Table 3). Further stability of the economy is not able to be "guided" only by the discount rate and the currency intervention. Governments are not always professionally involved in government to minimize shocks.

In addition, the economy is observed:

- insufficient investment, problems with timely use of money by financial institutions and other funds for infrastructure projects;

- the share of non-performing loans in the Ukrainian economy reached 54\%;

- compensation to individual enterprises in the form of benefits, subsidies, etc.

In 2018, we have struggled with the results of non-market price increases, turbulence in foreign markets and a decline in investor interest in Ukraine. At the same time, the relative stability of the hryvnia was observed, during the year the dynamics of replenishment of gold and currency reserves was positive.

Table 3. Indicators of economic growth and population growth in Ukraine in 2014-2018

\begin{tabular}{|c|c|c|c|c|c|c|c|}
\hline Key Indicators & 2014 & 2015 & 2016 & 2017 & 2018 & $\begin{array}{l}2019 \\
\text { forecast }\end{array}$ & $\begin{array}{l}2020 \\
\text { forecast }\end{array}$ \\
\hline 1 & 2 & 3 & 4 & 5 & 6 & 7 & 8 \\
\hline GDP, billion UAH & 1567 & 1979 & 2385 & 2983 & 3483 & 3918 & 4348 \\
\hline GDP, real, apc & $-6,6$ & $-9,8$ & 2,4 & 2,5 & 3,0 & 2,3 & 2,6 \\
\hline Consumption, real, rvs & $-6,2$ & $-15,2$ & 2,0 & 7,1 & 3,5 & 2,1 & 2,1 \\
\hline $\begin{array}{l}\text { Gross fixed capital accumulation, } \\
\text { real, apc }\end{array}$ & $-24,0$ & $-9,2$ & 20,4 & 18,2 & 14,0 & 8,0 & 8,0 \\
\hline Industrial production, real, apc & $-10,1$ & $-13,0$ & 2,8 & 0,4 & 1,7 & 2,2 & 2,4 \\
\hline Agricultural production, real, apc & 2,2 & $-4,8$ & 6,3 & $-2,7$ & 8,0 & 0,0 & 3,0 \\
\hline $\begin{array}{l}\text { Population at the beginning of the } \\
\text { year, million people }\end{array}$ & 45,5 & 45,3 & 45,2 & 45,1 & 44,9 & 44,8 & 44,7 \\
\hline 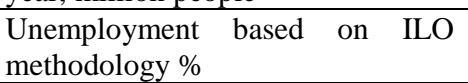 & 9,3 & 9,1 & 9,3 & 9,5 & 9,0 & 8,5 & 8,0 \\
\hline Consumer Price Index, ac & 24,9 & 43,3 & 12,4 & 13,7 & 10,0 & 6,8 & 6,0 \\
\hline Producer price index, ac & 31,7 & 25,5 & 35,7 & 16,5 & 16,0 & 10,0 & 9,0 \\
\hline Exports of goods and services, apc & $-19,9$ & $-26,9$ & $-3,9$ & 17,1 & 10,0 & 4,5 & 4,3 \\
\hline Imports of goods and services, apc & $-28,1$ & $-29,3$ & 4,5 & 19,2 & 14,5 & 2,8 & 3,4 \\
\hline Current account balance, $\%$ of GDP & $-3,5$ & 1,8 & $-1,4$ & $-2,2$ & $-4,3$ & $-3,8$ & $-3,5$ \\
\hline Direct investments, million USD USA & 299 & 3012 & 3268 & 2593 & 2300 & 2500 & 2500 \\
\hline Money base, apc & 8,5 & 0,8 & 13,6 & 4,6 & 6,0 & 5,0 & 4,0 \\
\hline $\begin{array}{l}\text { International reserves of the NBU, } \\
\text { mln. USA }\end{array}$ & 7533 & $\begin{array}{l}13 \\
300\end{array}$ & $\begin{array}{l}15 \\
539\end{array}$ & $\begin{array}{l}18 \\
808\end{array}$ & $\begin{array}{l}19 \\
000\end{array}$ & 18000 & 17000 \\
\hline $\begin{array}{l}\text { Official exchange rate, average for } \\
\text { the year, }\end{array}$ & 11,89 & 21,84 & 25,55 & 26,60 & 27,30 & 29,50 & 31,00 \\
\hline $\begin{array}{l}\text { Rate for loans in national currency, } \\
\text { at the end of the year, } \% \text { per annum }\end{array}$ & 16,6 & 20,4 & 15,2 & 17,5 & 22,0 & 20,0 & 18,0 \\
\hline
\end{tabular}

at the end of the year, $\%$ per annum

Source: Based on Economic Analysis and Trends: Forecast for 2018-2020, ICPS, 2018 [20] 
At the same time, asymmetry in foreign trade and insufficient lobbying of national interests remained. According to the State Statistics, the negative balance of the foreign trade balance of Ukraine in 2018 amounted to $\$ 3.45$ billion. For comparison, for the same period of 2017 the negative balance of the foreign trade balance was $\$ 1.11$ billion [21]. The introduction of medium-term planning has added to the predictability of the Ukrainian economy. It is difficult to apply such an approach in the realities of Ukraine. Especially without reducing the vulnerability to internal and external shocks. Accordingly, any plans can be easily "spoiled" in a turbulent environment. In addition, most indicators of Ukrainian plans are set manually and depend on the "mood" of the government, that is, they are static rather than dynamic. They do not automatically change based on formula calculations and depending on the situation. Indicators do not guarantee the timely updating of plans, they do not guarantee their relevance and independence from government decisions.

The following scenarios remain:

The baseline scenario is most likely. According to him, the transitional government will not make significant changes and implement reforms. The Ukrainian economy will continue its stagnant development trend. Under such conditions, there will be no opposition from interested parties and the government will be able to fulfill its functions.

In the case of a negative scenario, there may be a blockage of transitional government decisions, uncertainty in intentions and no time for maneuver. Ukraine risks not even getting an IMF tranche and not paying its debts. This could result in a financial crisis in the country.

However, every year Ukraine is gaining experience and its development can be extremely fruitful. Measures such as the fight against corruption, the reform of the judiciary, the modernization of the education system, the development of the financial sector, the improvement of the investment climate by reducing the regulatory burden on business and the implementation of transparent and equal rules of the game are needed to support the real economy.

The main initiative is to go from business to state support. It is necessary to create national and regional 4.0 platforms, following the example of EU countries, bringing together government institutions, businesses and scientists. The task is to perform forecast growth indices of the country (Table 5).

Table 5. Indices of industrial production, exports and consumer expenditures in Ukraine in 2013 and 2017-2019 (\%)

\begin{tabular}{|l|l|l|l|l|}
\hline Indicator & $\mathbf{2 0 1 3}$ & $\mathbf{2 0 1 7}$ & $\mathbf{2 0 1 8}$ & $\mathbf{2 0 1 9}$ (forecast) \\
\hline Index of industrial production & 99,0 & 97,1 & 95,0 & 84,6 \\
\hline Index of goods and services exports & 46,9 & 47,9 & 45,3 & 51,5 \\
\hline Consumer expenditure index & 92,8 & 85,6 & 89,8 & 85,5 \\
\hline
\end{tabular}

Source: [26]

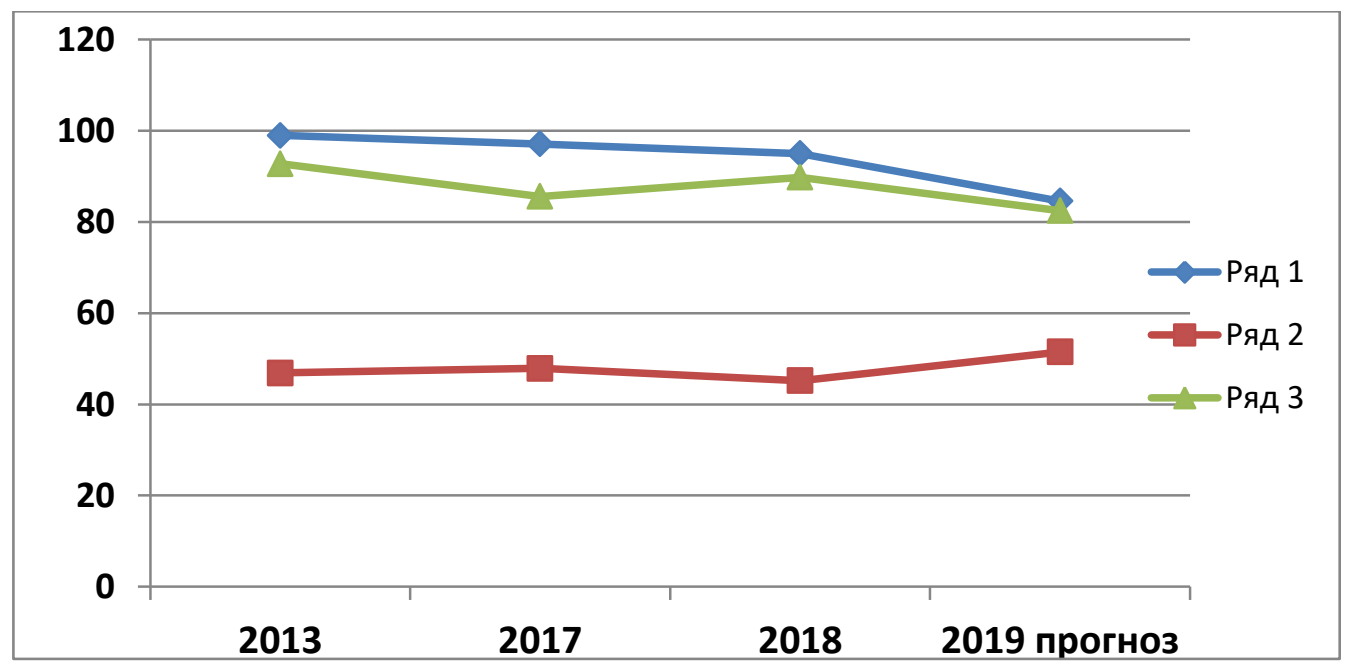

Fig. 2. Indices of industrial production, exports and consumer spending in Ukraine in 2013 and 2017-2019

Source: [26] 
The index of industrial production is defined as the ratio of the current volume of production to the volume of industrial production in the previous period. Given the limited budget financing, there are no plans to launch large-scale new state aid programs for industrial enterprises in the form of tax breaks or direct subsidies. Instead, it is urgent to analyze the effect of pre-existing benefits and to draw conclusions about their appropriateness. If there is a positive effect of state aid on the development of the industry, assistance should be provided in accordance with the following principles: it should arrive on time and at the address.

Ukraine has managed to improve its budget deficit situation. Today, the budget deficit is at $2 \%$ of GDP, which is quite reasonable. Anti-corruption institutes have been established in the country, including the National Anti-Corruption Bureau and the Anti-Corruption Court. In many countries neighboring Ukraine, such institutes have not yet been established. Ukraine has managed to create a transparent system of public procurements online, Transparent, which really saves money. Ukraine has reformed corporate governance in some large state-owned companies. The banking sector was cleaned by closing about half of the banks with venture capital.

Along with the currency strength indicator, an important competitiveness of the economy and the level of exports. Ukraine has failed to raise the level of development of processing and high-tech industries. The Government worked on the development of an Industrial Development Strategy for two years, but the document was not finally adopted. The country is still determining what public administration really needs to develop the real sector as a basis for economic growth.

Impact on economic development has deep factors. First of all, the impact on the balance of the economy at the stage of reform development is in the mechanism of resource allocation. "The essence of the mechanism for allocating scarce resources," explains S. Guriev, 2018 , "is that individual institutions of the economic system, using certain advantages of their position (high concentration of production and capital, corporate power), do not have the ability to consciously influence production parameters even on a local, limited scale [28].

Among the most serious consequences of the functioning of corporate mechanisms of resource allocation can be noted the divergence of the country, which has occurred in recent years, into strongly and weakly corporatized "sectors". In practice, there is a steady shift in prices, financing, lending in favor of a highly corporatized sector, and the cause of such a shift is not only monopoly, which gives this sector significant advantages in the market, but also imbalance in the distribution of corporate and state power, which creates an institutional «advantage the first sector over the second "[28].

It is the "potential difference" resulting from the divergence of the economy of the two "sectors" that becomes, in the current context, the main source for polarizing social structures and relationships. The immediate effects of the polarization of the economic space, which plays a significant role in creating an environment for structural imbalances and the shadow economy, should be intensified by the struggle for income redistribution, which is unevenly distributed at all levels.

Conclusions. The solution to the problems of state regulation of economic processes in developing market countries is based on the disclosure of the mechanisms of reforming their economies. The seriousness of the problems, both for Ukraine and for other countries with a transformational transition economy, determines the same mechanisms for reforming the economic system, political system and public administration system.

Improving methodological tools for assessing the level of economic development of the country requires taking into account the balance in the system of indicators of macroeconomic development. Reforming economic systems is determined first by political changes, and then by economic ones. The process of transformational change in the economy of the countries is dependent, secondary. It is governed from above by state-power structures. The low interest of the citizens and the peculiarities of their motivation are a consequence of the fact that the power structures do not create the conditions for the modern needs of the motivation to change in general.

The situation today is that state corporations, industry monopolies, individual oligarchs and power structures have a special influence on the economic development of the country. Because of this impact, the opportunities given to countries during certain periods of their historical development are lost. Strong political groups, oligarchs, "predatory elites" dictate their terms. They influence the directions of use of financial resources, the development of sectors, segments, industries.

Fundamentals of economic theory argue that conditions for the growth and modernization 
of the economy are created in the real sector. Stagnation of industry as a major element of the national economy largely causes the weakening of the national economy as a whole. It should be borne in mind that this implies the need to align monetary policy priorities with those of a balanced sectoral development at the state level and to ensure that they are complied with.

In countries where the share of the processing sector is low, commodity exports are subject to oligarchic influence. Funds exported through commodity exports are most often a source of funding for development programs for countries. Therefore, there is a need to bring macroeconomic and monetary development priorities closer to those of the real economy. The impact of the imbalance crisis in countries is exacerbated by the weak growth of raw materials processing enterprises and the extension of value chains and the lack of domestic producers in value chains.

An urgent need to accelerate the economic growth of countries with a transformational economy in the current circumstances is to introduce a maximum degree of economic freedom for actors participating in the sectoral markets, with the maximum requirement of their social responsibility. This demand should change the situation with the spread of socio-political populism, which to date has a significant impact on the Ukrainian economy and the economy of other countries.

\section{References:}

1. Економічний енциклопедичний словник / Ред.-упоряд. С. В. Мочерний. Т. 2. Львів : Світ, 2015. $568 \mathrm{c}$.

2. Савельєв Ю. Б. Багатовимірна сучасність: соціальне включення в оцінці соціального розвитку : монографія. Київ : ВПЦ "Київський університет", 2017. 447 с.

3. Misconceptions of Measurement Equivalence (2015): Time for a Paradigm Shift Christian Welzel Leuphana University Lüneburg Ronald Inglehart University of Michigan at Ann Arbor World Values Research WVR Volume 8 / Number 5 / 2015 URL : http://www.sociology.kpi.ua/wpcontent/uploads/2016/02/F00005675-WVR_08_05_Welzel_Inglehart.pdf.

4. Державна служба статистики України. Київ : Інформаційно-аналітичне агентство, 2018. URL :www.ukrstat.gov.ua.

5. Данилишин Б. НБУ - це не ФРС. Банк Англії чи Національний банк Швейцарії. Регулятор діє не зовсім «за розміром одягу». День, 2019, № 21. URL: https://day.kyiv.ua/uk/article/ekonomika/nbu-ce-ne-frs-bank-angliyi-chy-nacionalnyy-bank-shveycariyi.

6. Hokenos, P. Globalization and its Discontents Revisited. Nobel Prize-winning economist Joseph Stiglitz says workers and citizens are missing out on the benefits of globalisation. URL : https://www.ips-journal.eu/book-reviews/article/show/globalization-and-its-discontents-revisited-2708/.

7. Farrell, H. Free Market - Impossible Utopia: Criticism of Charles Polanyi. The Washington Post. July 18, 2014.

8. Polanyi, John (2010). Freedom, indivisible. The Globe and Mail. URL : https://www.thecanadianencyclopedia.ca/en/article/john-charles-polanyi.

9. Buchanan, J. M. (1986). The limits of liberty: Between anarchy and Leviathan. Chicago : Harper.

10. Стиглиц Дж. Крутое пике: Америка и новый экономический порядок после глобального кризиса ; пер. с англ. В. Лопатка. М. : Эксмо, 2011. 512 с.

11. Global Economis Prospects Report (2019), Worldbank/ Global-Economic-Prospects-June2019-Regional-Overview-ECA-RU.pdf URL : http://pubdocs.worldbank.org/en/3557115554278238/ Global-Economic-Prospects-June-2019-Regional-Overview-ECA-RU.pdf.

12. Варналій 3. С., Хмелевська Л. П. Особливості та перспективи розвитку економіки знань в Україні. Вісник Київського національного університету технологій та дизайну. Серія : Економічні науки. 2017. № 2. C. 7-14. URL : http://nbuv.gov.ua/UJRN/vknutden_2017_2_3.

13. Євтушенко Н. М., Макарчук I. М., Яременко Л. М. Макроекономічна стабільність в Україні. Молодий вчений. 2016. №3. URL : http://molodyvcheny.in.ua/files/journal/2016/3/19.pdf.

14. Macroeconomic Stability (2016). The Reut Institute. URL : http://reut- institute.org/Publication.aspx?PublicationId=1299.

15. Schwab K. The Global Competitiveness Report 2011-2012 - World Economic Forum. URL : http://reports.weforum.org/global-competitiveness-2011-2012/.

16. Essays in the Theory of Economic Growth. By Evsey D. Domar. New York: Oxford University Press [Toronto: Oxford University Press]. 1957. Pp. x, 272.

17. The Trade Cycle. By R. F. Harrod. Oxford: Clarendon Press. 1936. Pp. ix, 234. (10s.)

18. Население, капитал и экономический рост. (1973); URL: http://berkovichzametki.com/2014/Zametki/Nomer2/Kuksin1.php.

19. Causa, O. and Hermansen, M. (2018). "Redistribution of Income from Taxes and Transfers by OECD Countries", OECD Working Papers on Economics. 1453, Paris, URL : http://dx.doi.org/10.1787/bc7569c6-ua.

20. Економічний аналіз і актуальні тенденції: прогноз на 2018-2020 роки (2018), МЦЗПД.

URL: http://icps.com.ua/holovni-ekonomichni-trendy-pershoho-pivrichchya-2018-roku--makroekonomichnyy-prohnoz-mtspd/.

21. Негативне сальдо зовнішньої торгівлі за 2018 рік зросло більш ніж у два рази (2018). URL: www.rbc.ua/ukr/news/ отрицательное-салдо-внешне-торговли-2018-1550159738.html.

22. Використання основних інструментів грошово-кредитної політики і методів грошово- 
кредитного регулювання. URL : http://bank.gov.ua/control/uk/publish/article?art_id=123274\&cat_id12. 23. Особливості виконання меморандуму МВФ у 2019 році. URL: http://icps.com.ua/osoblyvosti-vykonannya-memorandumu-mvf-u-2019rotsi.

24. Тітамир О. За яких умов ставки за банківськими кредитами можуть знизитися? 3 квітня 2019 року. URL: https://lb.ua/blog/oleh_titamyr/423666_yakih_umov_stavki_bankivskimi.html.

25. Новак А. Як підняти українську економіку? Трифункціональна економічна модель України: Монографія. Вид. 3-є, доп. К. : Гнозіс, 2011. 368 с.

26. Звітні макропоказники розвитку України у 2016-2018 роках. URL : http://www.minfin.gov.ua/uploads/redactor/files/pdf.

27. Как Украине начать догонять Европу. Рецепт Сергея Гуриева (2018). URL : https://biz.liga.net/ekonomika/ all/opinion/kak-ukraine-nachat-dogonyat-evropu-retsept-sergeya-gurieva.

28. Сергей Гуриев: «Ситуация в Украине гораздо лучше, чем то, что думают и пишут об Украине в России». 4 декабря 2018 года. URL: https://newtimes.ru/articles/detail/173903.

29. Козюк В. Олигархическая гидра прямых иностранных инвестиций. Зеркало недели. Вып. 13, 6-12 апреля 2019. URL: https://zn.ua/finances/oligarhicheskaya-gidra-pryamyh-inostrannyhinvesticiy-ot-makrofinansovoy-nestabilnosti-k-tehnologicheskomu-otstavaniyu-291385_.html

30. Лещенко Р.М. Фінансово-правове регулювання офшорних механізмів: Монографія. К. : Юрінком Інтер, 2018. $646 \mathrm{c}$.

31. Прісняков В. Ф. Тіньова економіка і методи визначення ії обсягу. Фінанси Украйни. 2001. №7. C. 3-8.

Received to editorial office 24.11.2019

1. Ekonomichny`j ency`klopedy`chny`j slovny`k (2015) [Economic Encyclopedia Dictionary] / red.-uporyad. S.V. Mocherny`j. T. 2. L'viv: Svit,. 568 s. [in Ukr.]

2. Savel`yev, Yu. B. (2017). Bagatovy`mirna suchasnist`: social’ne vklyuchennya v ocinci suspil nogo rozvy`tku [Multidimensional modernity: social inclusion in the assessment of social development]: monografiya / Yu. B. Savel`yev. K. : VPCz "Ky`yivs`ky`j universy`tet", 447 s. [in Ukr.]

3. Misconceptions of Measurement Equivalence (2015): Time for a Paradigm Shift Christian Welzel Leuphana University Lüneburg Ronald Inglehart University of Michigan at Ann Arbor World Values Research WVR Volume 8 / Number 5 / 2015 URL : http://www.sociology.kpi.ua/wpcontent/uploads/2016/02/F00005675-WVR_08_05_Welzel_Inglehart.pdf

4. Derzhavna sluzhba staty`sty`ky Ukrayiny`(2018). Kiyv Informatciino-analitichne ahentstvo www.ukrstat.gov.ua [in Ukr.]

5. Dany`ly`shy`n, B. (2019). NBU- ce ne FRS. regulyator diye ne zovsim «za rozmirom odyagu» [NBU is not the Fed. The regulator does not work at all "by the size of clothes"] Vy'dannya «Den `» 21, 5 lyutogo, 2019 r. URL : https://day.kyiv.ua/uk/article/ekonomika/nbu-ce-ne-frs-bankangliyi-chy-nacionalnyy-bank-shveycariyi [in Ukr.]

6. Stiglicz, D. (2003). Globalizaciya ta yiyi nevdovolennya. [Globalization and its discontents]. Great Britain: Allen Lane The Penguin Press Freefall. URL : https://www.ips-journal.eu/bookreviews/article/show/globalization-and-its-discontents-revisited-2708/

7. Farrell, H. (July 18, 2014). Free Market - Impossible Utopia: Criticism of Charles Polanyi. The Washington Post. Retrieved January 11, 2015.

8. Polanyi, John (2010). "Freedom, indivisible". The Globe and Mail. URL : https://www.thecanadianencyclopedia.ca/en/article/john-charles-polanyi

9. Buchanan, J. M. (1986). The limits of liberty: Between anarchy and Leviathan / J. M. Buchanan. Chicago : Harper.

10. Sty`gly`cz, Dzh. (2011) Krutoe py`ke. Amery`ka y`novbij эkonomy`chesky ’j poryadok posle global nogo kry zy`sa [America and the new economic order after the global crisis] = Freefall: America, Free Markets, and the Sinking of the World Economy. M.: Эksmo.

11. Global Economis Prospects Report (2019), Worldbank/ Global-Economic-Prospects-June2019-Regional-Overview-ECA-RU.pdf URL : http://pubdocs.worldbank.org/en/3557115554278238/ Global-Economic-Prospects-June-2019-Regional-Overview-ECA-RU.pdf

12. Varnalij, Z. S., Xmelevs`ka, L. P. (2017) Osobly`vosti ta perspekty`vy` rozvy`tku ekonomiky znan ` v Ukrayini [Features and prospects of knowledge economy development in Ukraine]. Visny`k Ky`yivs`kogo nacional ’nogo universy`tetu texnologij ta dy`zajnu. Seriya : Ekonomichni nauky`. № 2. St. 7-14. Rezhy`m dostupu: http://nbuv.gov.ua/UJRN/ vknutden_2017_2_3 [in Ukr.]

13. Yevtushenko, N.M., Makarchuk, I.M., Yaremenko, L.M. (2016) Makroekonomichna stabil ’nist v Ukrayini [Macroeconomic Stability in Ukraine] Ekonomichni nauky', № 3, (30). URL : http://molodyvcheny.in.ua/ files/journal/2016/3/19.pdf [in Ukr.]

14. Macroeconomic Stability (2016) // The Reut Institute. [Elektronny`j resurs]. URL : http://reut- institute.org/Publication.aspx?PublicationId=1299.

15. Schwab K. The Global Competitiveness Report 2011-2012 / K. Schwab - World Economic Forum. URL : http://reports.weforum.org/global-competitiveness-2011-2012/.

16. Domar, Y. (1954) Teory 'y ' эkonomy 'cheskogo rosta. Kejnsy`anstvo. [Theories of economic growth. Keynesianism].

17. Harrod, R. Torgovel`ny $j$ cy ${ }^{k} k l$ [The Trade Cycle Monograph (1936) and The Theory of Economic Dynamics (1948) reprinted in Russia] Monografiya (1936) ta Do teoriyi ekonomichnoyi dy`namiky` (1948) perevy`dana u Rosiyi (M.: Ekonomika, 1997). 
18. Naseleny `e, kapy`tal y` эkonomy`chesky`j rost (Population, Capital and Growth, 1973); URL : http://berkovich-zametki.com/2014/Zametki/Nomer2/Kuksin1.php.

19. Causa, O. and Hermansen, M. (2018). "Redistribution of Income from Taxes and Transfers by OECD Countries", OECD Working Papers on Economics. 1453, Paris, URL : http://dx.doi.org/10.1787/bc7569c6-ua.

20. Ekonomichny`j analiz $i$ aktual `ni tendenciyi: prognoz na 2018-2020 roky`(2018) [Economic analysis and current trends: forecast for 2018-2020, ICPS], MCzPD. URL : http://icps.com.ua/holovniekonomichni-trendy-pershoho-pivrichchya-2018-roku---makroekonomichnyy-prohnoz-mtspd/ [in Ukr.]

21. Negaty`vne sal'do zovnishn`oyi torgivli za 2018 rik zroslo bil’sh nizh dva razy (2018) [The negative trade balance for 2018 has more than doubled] ' URL : www.rbc.ua/ukr/news/otritsatelnoe-saldovneshney-torgovli-2018-1550159738.html [in Ukr.]

22. Vy`kory`stannya osnovny`x instrumentiv ta metodiv monetarnoyi polity`ky` ta monetarnogoregulyuvannya (2018) [Use of the main monetary policy instruments and methods and monetary regulation]. URL : http://bank.gov.ua/control/uk/publish/article?art_id=123274\&cat_id12 [in Ukr.]

23. Osobly`vosti vy`konannya memorandumu MVF u 2019 roci Pres-sluzhba MCzPD 08.02.2019 [Features of the implementation of the IMF memorandum in 2019 ICPS press service on 02/08/2019]. URL : http://icps.com.ua/osoblyvosti-vykonannya-memorandumu-mvf-u-2019rotsi [in Ukr.]

24. Titamyr, O. Za yakykh umov stavky za bankivskymy kredytamy mozhut znyzytysia? 3 kvitnia 2019 [Oleg Titamir Under what conditions may the rates on bank loans decrease?] April 3, 2019. URL : https://ukr.lb.ua/oleh_titamyr/423666_yakih_umov_stavki_bankivskimi.html

25. Novak, A. (2011).'Yak pidnyaty` ukrayins`ku ekonomiku? Try`funkcional`na ekonomichna model Ukrayiny [How to raise the Ukrainian economy? Threefunctional economic model of Ukraine] Monografiya. Vy`d. 3-tye, dop. K.: «Gnozis», 368 s.[in Ukr.]

26. Zvitni makropokaznyky rozvytku ukrainy u 2016-2018 rokakh [Reporting macroeconomic indicators of Ukraine's development in 2016-2018]. URL https://www.minfin.gov.ua/uploads/redactor/files/pdf [in Ukr.]

27. Sergej Gury`ev Kak Ukray`ne nachat`dogonyat`Evropu (2018) [How Ukraine starts to catch up with Europe]. URL : https://biz.liga.net/ekonomika/ all/opinion/kak-ukraine-nachat-dogonyat-evropuretsept-sergeya-gurieva [in Rus.]

28. Gury`ev S.M. Sy`tuacy`ya v Ukray`ne spustya pyat` let posle revolyucy`y` dostoy`nstva [The situation in Ukraine is much better than what they think and write about Ukraine in Russia] The New Times 4 dekabrya 2018. URL : https://newtimes.ru/articles/detail /173903[in Rus.]

29. Kozyuk, V. (2019) Oly`garxy`cheskaya gy`dra pryamыx y`nostrannыx y`nvesty`cy`j [The oligarchic hydra of foreign direct investment]. Zerkalo nedely. Ukray`na. Vypusk 13, 6-12 aprelya. URL : https://zn.ua/finances/oligarhicheskaya-gidra-pryamyh-inostrannyh-investiciy-ot-makrofinansovoynestabilnosti-k-tehnologicheskomu-otstavaniyu-291385_.html [in Ukr.]

30. Leshhenko, R.M. (2019) Finansovo-pravove regulyuvannya ofshorny`x mexanizmiv [Financial and legal regulation of offshore mechanisms] : Monografiya. Vy`davny`cztvo Yurinkom. 646s. [in Ukr.]

31. Prisnyakov, V.F. (2014) Tin`ova ekonomika i metody`vy`znachennya yiyi obsyagu [The shadow economy and methods for determining its volume]. Finansy` Ukrayiny`. [in Ukr.]

\section{Summary}

The article deals with the problems of ensuring economic growth in emerging market economies: structural imbalances; STATE-managed, non-market financial and monetary policy; loss of opportunities for the development of the real sector of the economy; administrative failure of state-owned institutions.

Despite the significant amount and the high level of theoretical synthesis of these problems in existing scientific publications, their research remains relevant and requires additional scientific developments.

The author has considered the obstacles on the way of economic growth of countries, proposing their classification depending on their influence, origin and functional content. Among the impeding risks are precisely those such as weak state institutions, historically formed weak social structure, diametrically opposed interests of influential social groups, non-professionalism and miscalculations, etc.

The research is devoted to the development of conceptual foundations, principles and approaches to modeling the systems of economic growth in countries with market transformation. On the basis of the analysis of a representative mass of information, the relationship between the components that threatens economic growth, sustainable development of the countries is revealed; their repeatability or typology, which creates special conditions for the development of mechanisms for preventing obstacles, threats, risks and methods of managing them.

The author, using the methods of dialectics, scientific abstraction and the systematic approach, find out links and chain of links that characterize sectoral imbalances and macroeconomic imbalances and lead to them.

The results of the study allowed the authors to argue that the growing systemic crisis in the sociopolitical field of the state multiplicatively extended to the system of providing economic growth, which loses its functional capabilities and requires new and consistent strategic development priorities and its institutional and legal support, as well as mechanisms, instruments and means of transforming the market system.

Keywords: structural imbalances, real sector development, financial and monetary policy instruments, institutional and legal measures, development priorities. 